УДК 364:351.77:614.2

DOI 10.11603/2411-1597.2020.2.11245

\title{
МЕДИКО-СОЦІАЛЬНА РОБОТА В ЗАКЛАДАХ ОХОРОНИ ЗДОРОВ'Я
}

\author{
Н. А. Шульгіна \\ Миколаївська міська лікарня \\ Тернопільський національний медичний університет \\ імені І. Я. Горбачевського МОЗ Украӥни
}

У статті розкрито сутність медико-соціальної роботи як інтеграційного напряму в системі охорони здоров’я та соціальних служб.

\section{MEDICAL-SOCIAL WORK IN HEALTH CARE INSTITUTIONS}

\author{
N. A. Shulgina \\ Mykolaiv City Hospital \\ I. Horbachevsky Ternopil National Medical University
}

The article deals with the essence of medical and social work as an integration direction in the health care system and social services.

Вступ. Кризові явища в суспільно-політичному житті України, відсутність реального соціального захисту малозабезпечених, людей з обмеженими можливостями, низька якість медичного обслуговування, незадовільна екологічна ситуація спричиняють погіршення психосоматичного здоров'я населення, особистісне неблагополуччя, відчуття незахищеності. Інструментом реалізації комплексної соціальної політики країни, спрямованої на підвищення якості життя людей, є інтеграція медичної допомоги і соціальної роботи. Задля зниження соціального напруження в суспільстві необхідним стає впровадження нової професійної міждисциплінарної діяльності профілактичного, лікувально-діагностичного, психологічного, реабілітаційного та соціально-правового характеру, адекватних форм, методів і технологій медико-соціальної роботи, що сприятимуть збереженню, відновленню ізміцненню здоров'я населення.

Про актуальність теми дослідження свідчить низка наукових джерел стосовно надання медико-соціальної допомоги хворим у закладах охорони здоров'я (А. Гнезділов, Є. Грищенкова, В. Лехан, А. Мартиненко, С. Крюков, В. Чайковська та ін.). Питання теорії і практики медико-соціальної роботи досліджували В. Бочарова, І. Грига, Н. Зимовець, Г. Лактіонова,

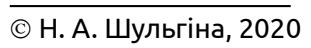

А. Мартиненко, Л. Тюптя, $Є$. Холостова та ін. Серед зарубіжних науковців варто відзначити Дж. Донеллі, Б. Еріксона, Ю. Хеймінга та ін.

Основна частина. Пріоритетним напрямом стратегії Всесвітньої організації охорони здоров'я (ВООЗ) 3 метою досягнення «здоров'я для всіх» $\epsilon$ політика, що сприяє зміцненню здоров'я. Вона спирається на формування здорового способу життя населення і розвиток реальних практичних дій зі збереження та зміцнення здоров'я. Необхідним складником задоволення основних здоров'язберігальних потреб населення $\epsilon$ сприяння адекватному розвитку медико-соціальної роботи. При цьому важливим $\epsilon$ як доступність і якість обслуговування, так і відповідне ресурсне забезпечення.

Передумовою становлення та розвитку медикосоціальної роботи як виду мультидисциплінарної професійної діяльності стали такі чинники:

1. Матеріали ООН, що підкреслюють значимість розвитку соціальної політики, спрямованої на забезпечення медичного та соціального захисту населення за умов кризи, і необхідність відпрацювання механізму реалізації соціальних гарантій за участю закладів охорони здоров'я.

2. Стратегія досягнення «здоров'я для всіх», розроблена Всесвітньою організацією охорони здоров'я, що 
ґрунтується на забезпеченні інтеграції медичної та соціальної діяльності, необхідності розвитку міжсекторального співробітництва.

3. Результати вітчизняних комплексних наукових досліджень проблем здоров'я і способу життя, що розкривають методологічні й методичні основи вивчення здоров'я населення, окремих груп, сімей, громад.

4. Сучасні підходи до реформування охорони здоров'я в Україні, що дозволяють створити правовий механізм відповідальності за стан здоров'я населення з боку держави й зацікавленості громадянина, роботодавця, лікувально-профілактичного закладу та інших суб'єктів охорони здоров'я людей; особливості розвитку медичного та соціального обслуговування населення в Україні на основі багатофакторної соціальної політики, надання соціально-медичних, психологічних, соціально-правових послуг, проведення реабілітації громадян, які перебувають у складній життєвій ситуації.

5. Історичні корені добродійності й милосердя в нашій країні, що дозволяють розглядати їх як етапи розвитку медичної та соціальної допомоги й основу становлення вітчизняної медико-соціальної роботи.

6. Зарубіжний досвід теорії та практики професійної медико-соціальної роботи, що нагромадився за останні десятиліття в економічно розвинених країнах.

\section{Концепція медико-соціальної роботи}

Дослідження сучасних проблем різних груп пацієнтів медичних установ і клієнтів соціальних служб свідчать про те, що значною складовою медикосоціальної роботи є медико-соціальна діяльність фахівців медицини. За даними досліджень, медикосоціальні проблеми виявляють не менш ніж у $40 \%$ пацієнтів із хронічними захворюваннями психіатричного, наркологічного й онкологічного профілів [1].

На основі аналізу вітчизняного досвіду становлення й розвитку медико-соціальної роботи, нинішньої демографічної ситуації в країні та врахування зарубіжних теорій вченими розроблено концепцію медико-соціальної роботи як нового виду мультидисциплінарної професійної діяльності.

За умов зниження показників громадського здоров'я зростає об'єктивна потреба у вирішення взаємозалежних проблем медичного й соціального характеру на якісно новому рівні - діяльності комплексноінтегративного характеру в рамках професійної діяльності, пов'язаної з відновленням, збереженням та зміцненням здоров'я - медико-соціальної роботи.
Специфіка змісту і методів медико-соціальної роботи дозволяють розглядати ії як самостійний напрямок багатоаспектної професійної діяльності.

Основні поняття і категорії медико-соціальної роботи

Нині практика медико-соціальної роботи передбачає декілька напрямків діяльності, що проявляються в широкому різноманітті їі застосування. Така ситуація вимагає дослідження суті медико-соціальної роботи як важливого аспекту професійної діяльності медичних працівників, що має на меті оптимізувати реалізацію суб'єктної ролі людей в процесі задоволення потреб, підтримки й життєзабезпечення особистості.

Важливим компонентом медико-соціальної роботи $\epsilon$ забезпечення взаємодії життєвих сил людини і соціальних систем [1]. Англійські вчені Ш. Рамон і Т. Шанін визначають соціальний аспект медико-соціальної роботи як організацію допомоги людям, основаної на альтруїзмі й спрямованої на те, щоб полегшити людям повсякденне життя, а також, по можливості, кардинально вирішити особистісні проблеми [2]. Підкреслює соціальний аспект медико-соціальної роботи Роберт л. Беркер, вважаючи, що практика такої роботи спрямовується на забезпечення:

- допомоги людям в отриманні послуг (обслуговування);

- консультування та психотерапевтичної допомоги інвалідам, сім'ям, групам;

- допомоги в налагодженні й поліпшенні спільної діяльності закладів охорони здоров'я та соціальних служб;

- участі у відповідних правових процесах [1].

$\mathrm{y}$ «Глосарії термінів медико-соціальної допомоги» Європейського регіонального бюро охорони здоров'я подано таке визначення медико-соціальної роботи: «Організоване медичне і соціальне обслуговування, що охоплює широке коло медико-соціальних проблем людей шляхом дослідження конкретних випадків і використання інших спеціалізованих методів». У цьому ж виданні медико-соціальну роботу трактують як «Організоване обслуговування в лікарнях або інших закладах, де особливий акцент робиться на вирішення соціальних проблем, пов'язаних зі здоров'ям людини» [1].

Наведемо деякі напрямки спеціалізації, що представляють особливий інтерес з метою збереження й зміцнення здоров'я людини:

- медико-соціальна робота з населенням; 
- медико-соціальна робота в закладах охорони здоров'я;

- медико-соціальна допомога людям літнього віку та інвалідам в умовах стаціонарних установ.

Медико-соціальна робота значно ширша за медико-соціальну допомогу і вимагає більш деталізованого тлумачення. Медико-соціальну роботу розглядають як діяльність, спрямовану на відновлення і збереження фізичного та психічного здоров'я (індивіда, колективу) для досягнення соціального благополуччя.

Метою медико-соціальної роботи деякі фахівці вважають поліпшення функціонування пацієнта/клієнта/ особи і його адаптація до умов соціального оточення, здійснення сприятливих змін у житті особи.

Інтегруючи підходи вітчизняних і закордонних вчених до визначення сутнісного змісту медикосоціальної роботи, доречно конкретизувати три аспекти такого виду діяльності:

1) надання медичної та соціальної допомоги окремій людині або групі осіб у складній життєвій ситуації шляхом реабілітації, консультування, використання інших видів медико-соціальних послуг;

2) розвиток потенціалу самодопомоги осіб, які потрапили в складну життєву ситуацію;

3) вплив на формування й реалізацію соціальноекономічної політики на всіх рівнях із метою забезпечення соціально здорового середовища життєдіяльності людини, створення системи підтримки осіб, які потребують допомоги.

Зазначені три аспекти становлять основу змісту й медико-соціальної роботи як виду професійної діяльності при наданні медико-соціальної допомоги. Необхідно відзначити, що медико-соціальна допомога включає профілактичну, лікувально-діагностичну, реабілітаційну, протезно-ортопедичну й зубопротезну допомогу, заходи соціального характеру з догляду за хворими, непрацездатними та інвалідами, а також виплати допомоги з тимчасової непрацездатності.

\section{СПИСОК ЛІТЕРАТУРИ}

1. Анафьянова Т. В. Особенности социально-медицинской работы с лицами и группами девиантного поведения в регионе / Т. В. Анафьянова. - М. : «Академия естествознания», 2011. - 238 с.

2. Артьоменко В. В. Симуляційне навчання в медицині: міжнародний та вітчизняний досвід / В. В. Артьоменко // Одеський медичний журнал. - 2015. - № 6 (152). - С. 67-74.
Специфіка діяльності, яка спрямована на надання медико-соціальної допомоги, визначає особливості медико-соціальної роботи як важливої прикладної складової соціальної медицини, яку використовують:

1) у наукових дослідженнях соціальних факторів, які впливають на здоров'я або захворюваність і їх проводять за допомогою вивчення випадків захворюваності та методів прогнозування;

2) через встановлення існуючих взаємозв'язків між медициною й суспільством (медична соціологія), включаючи колективну відповідальність медицини перед суспільством за консультування з соціальних проблем, які впливають на здоров'я;

3) у соціальній психології та соціальній психіатрії;

4) у закладах соціальної терапії, службах соціального страхування і охорони громадського здоров'я, медичної допомоги та добробуту.

Розвиток теорії і практики вітчизняної системи охорони здоров'я вносить свої корективи й уточнення до зазначеного визначення, враховуючи сутність соціальної медицини:

1) соціальна медицина вивчає соціальні фактори, які впливають на здоров'я людини;

2) соціальна медицина досліджує форми і методи, спрямовані на збереження здоров'я і запобігання розвитку захворювань;

3) соціальна медицина долучає в роботу закладів охорони здоров'я діяльність соціальних працівників, спрямовану на відновлення й збереження здоров'я людини [3]

Висновки. Медико-соціальна робота - це вид професійної діяльності, що сприяє відновленню, збереженню й зміцненню здоров'я шляхом вирішення проблем пацієнта/клієнта, який опинився в складній життєвій ситуації. Таким чином, медико-соціальна робота $є$ важливим компонентом соціальної медицини, що має виражений прикладний характер.

3. Беллі П. Як працює система? Новий підхід до аналізу і оцінки процесів управління в системі охорони здоров'я в Україні / П. Беллі, Ю. Джигир, К. Майнзюк. - К. : Світовий банк, 2015. - 224 с.

Отримано 02.04.20 